Article

\title{
Effect of Sodium Sulfite on Floatability of Chalcopyrite and Molybdenite
}

\author{
Hajime Miki *, Tsuyoshi Hirajima ${ }^{(D)}$, Yukihiro Muta, Gde Pandhe Wisnu Suyantara ${ }^{(D)}$ and \\ Keiko Sasaki \\ Department of Earth Resources Engineering, Faculty of Engineering, Kyushu University, 744 Motooka, \\ Nishi-ku, Fukuoka 819-0395, Japan; hirajima@mine.kyushu-u.ac.jp (T.H.); mmuuttb429@gmail.com (Y.M.); \\ pandhe@mine.kyushu-u.ac.jp (G.P.W.S.); keikos@mine.kyushu-u.ac.jp (K.S.) \\ * Correspondence: miki@mine.kyushu-u.ac.jp
}

Received: 14 March 2018; Accepted: 16 April 2018; Published: 22 April 2018

\begin{abstract}
Sodium hydrogen sulfide (NaHS) is commonly used as a copper depressant in the selective flotation of copper and molybdenum ores. However, the process is facing health and safety issues because $\mathrm{NaHS}$ readily yields toxic hydrogen sulfide gas $\left(\mathrm{H}_{2} \mathrm{~S}\right)$ under acidic conditions. In this study, $\mathrm{Na}_{2} \mathrm{SO}_{3}$ was proposed as an alternative copper depressant. The effect of $\mathrm{Na}_{2} \mathrm{SO}_{3}$ on the surface wettability and floatability of chalcopyrite and molybdenite-typical copper and molybdenum minerals, respectively - was intensively studied using contact angle measurements and flotation tests. Contact angle readings show that the chalcopyrite surface became hydrophilic after the $\mathrm{Na}_{2} \mathrm{SO}_{3}$ treatment. Meanwhile, the molybdenite surface was relatively more hydrophobic compared with that of chalcopyrite after the treatment. Flotation tests using pure minerals of chalcopyrite and molybdenite demonstrate that the floatability of chalcopyrite decreased with increasing concentration of $\mathrm{Na}_{2} \mathrm{SO}_{3}$. On the other hand, the floatability of molybdenite gradually increased under similar conditions, suggesting that $\mathrm{Na}_{2} \mathrm{SO}_{3}$ might have the potential to be used for selective flotation of chalcopyrite and molybdenite. A possible mechanism is proposed in this study to explain the phenomenon using $X$-ray photoelectron spectroscopy analysis.
\end{abstract}

Keywords: selective flotation; molybdenite; chalcopyrite; $\mathrm{Na}_{2} \mathrm{SO}_{3} ; \mathrm{NaHS}$ alternative; XPS

\section{Introduction}

Many copper mines often produce associated molybdenum minerals as trace minerals. It is important to separate molybdenum and copper minerals efficiently because molybdenum minerals are valuable minerals. Moreover, contamination of molybdenum minerals in the copper concentrate reduces the concentrate value. The conventional separation of copper and molybdenum $(\mathrm{Cu}-\mathrm{Mo})$ ores has been achieved with sulfide ore bulk flotation followed by selective molybdenum flotation with the addition of a copper sulfide depressant (i.e., sodium hydrogen sulfide (NaHS), sodium thioglycollate $\left(\mathrm{HSCH}_{2} \mathrm{COONa}\right)$, sodium sulfide $\left(\mathrm{Na}_{2} \mathrm{~S}\right)$, Nokes reagent $\left(\mathrm{P}_{2} \mathrm{~S}_{5}+\mathrm{NaOH}\right)$, and sodium thiopropionate $\left(\mathrm{HSCH}_{2} \mathrm{CH}_{2} \mathrm{COONa}\right)$ ) [1-7]. NaHS is used most extensively in the conventional $\mathrm{Cu}-\mathrm{Mo}$ flotation process, where chalcopyrite and molybdenite are the main copper and molybdenum minerals, respectively $[3,8]$.

However, the existing $\mathrm{Cu}-\mathrm{Mo}$ flotation process shows imperfect molybdenite recovery $[9,10]$. Moreover, NaHS is a dangerous, corrosive, and toxic reagent. It needs to be used under specific conditions (i.e., alkaline conditions) to prevent the formation of toxic hydrogen sulfide gas $\left(\mathrm{H}_{2} \mathrm{~S}\right)$, which is usually formed under acidic conditions. Needless to say, there are environmental and safety needs to replace this highly toxic reagent with more environmentally friendly chemicals [11]. Therefore, better and safer methods are needed to separate copper and molybdenum minerals. 
The true role of NaHS as a depressant is not well understood; however, it might act as a reductant $[2,8]$. Therefore, it might be hypothesized that other reductants might give a similar effect. Sulfite and thiosulfates are known as strong reductants. Sodium sulfite $\left(\mathrm{Na}_{2} \mathrm{SO}_{3}\right)$ was used as a pyrite depressant in separation of sphalerite and pyrite using flotation [12] and in a complex ore containing enargite and chalcopyrite [13]. Houot and Duhamet [14] reported that sodium sulfide $\left(\mathrm{Na}_{2} \mathrm{~S}\right)$ depressed the floatability of chalcopyrite in the presence of dialkyl-thionocarbamate as a collector. However, the effect of sodium sulfite on the floatability of chalcopyrite and molybdenite has not yet been investigated. Therefore, this study focused on the effect of sodium sulfite on surface wettability and floatability of chalcopyrite and molybdenite.

\section{Materials and Methods}

\subsection{Materials}

Pure crystals of chalcopyrite (Miyatamata mine, Akita, Japan) and molybdenite (Hirase mine, Gifu, Japan) were used as experimental samples in this study. For contact angle measurements, the mineral crystal was cut as a flat surface and then was cast in an epoxy resin. The surface was polished and cleaned following the procedure described by Suyantara et al. [15,16]. For flotation experiment and X-ray photoelectron spectroscopy (XPS) analysis, the chalcopyrite was ground by agate mortar and pestle and was dry screened $(<38 \mu \mathrm{m})$. Fine powder molybdenite $(<30 \mu \mathrm{m})$ was supplied by Sumitomo Metal Mining Co., Ltd (Tokyo, Japan). The mineral powders were cleaned using $1 \mathrm{M} \mathrm{HNO}_{3}$ aqueous solution following the procedures described by Suyantara et al. [15]. Millipore ${ }^{\circledR}$ (Direct-Q, Merck, Japan) ultra-pure water with resistivity of $18.2 \mathrm{M} \Omega \cdot \mathrm{cm}$ was used in all experiments. $\mathrm{KOH}$ and $\mathrm{HCl}$ were used as $\mathrm{pH}$ modifiers. $\mathrm{Na}_{2} \mathrm{SO}_{3}$ was used for mineral treatment and methyl isobutyl carbinol (MIBC) was used as a frother in the flotation tests. Industrial grade diesel oil, TX15216 (alkyl mercaptan) from Nalco (Naperville, IL, USA) and AERO ${ }^{\circledR}$ MX-7017 (modified thionocarbamate) from Cytec (Woodland Park, NJ, USA) were used as flotation collectors.

\subsection{Contact Angle Measurements}

For contact angle measurements, the polished mineral surfaces were pretreated with various collectors. The surface pretreatment was conducted by mixing the collectors (i.e., TX15216 (6.0 mg/L), AERO $^{\circledR}$ MX-7017 (5.5 mg/L), and diesel oil (5.4 mg/L)) using a food blender TM900 (Tescom, Tokyo, Japan) at 12,000 rpm for $1 \mathrm{~min}$. The mixture is referred to as TMD (TX15216, MX-7017, and diesel oil) solution in this work. The polished mineral surfaces were added into the TMD solution and the $\mathrm{pH}$ was controlled at a desired value $(8,9,10.8$, or 11.5$)$ for $10 \mathrm{~min}$. Following the sample pretreatment, the mineral was treated in various concentrations of $\mathrm{Na}_{2} \mathrm{SO}_{3}$ for various treatment times $(10,30$, and $60 \mathrm{~min})$. Afterwards, contact angle measurements were carried out using a goniometer (Dropmaster 300, Kyowa Interface Science Co., Ltd., Saitama, Japan). The contact angle was measured using the bubble captive method following the procedures described in previous work [17,18].

\subsection{X-ray Photoelectron Spectroscopy (XPS)}

XPS analysis was performed to analyze the chemical composition of the surface before and after the $\mathrm{Na}_{2} \mathrm{SO}_{3}$ treatment. The mineral powders (ca. $1 \mathrm{~g}$ ) were treated in $0.1 \mathrm{M} \mathrm{Na}_{2} \mathrm{SO}_{3}$ and the mixture $\mathrm{pH}$ was controlled at various values $(8,10$, and 11.5) for $60 \mathrm{~min}$. The sample was then filtered and freeze-dried for 1 day. Afterwards, XPS analysis was conducted for untreated and treated minerals by following the procedure applied in Hirajima et al. [19]. The X-ray photoelectron spectra of the mineral were collected using AXIS 165 (Shimadzu-Kratos Co., Ltd., Manchester, UK) with an Al K $\alpha$ X-ray source $(1486.6 \mathrm{eV})$ operated at $105 \mathrm{~W}$ and a charge neutralizer. The analysis area was $1 \mathrm{~mm} \times 1 \mathrm{~mm}$ and the pressure in the analyzer chamber was $10^{-8} \mathrm{~Pa}$. The collected spectra were analyzed with Casa XPS (Ver. 2.3.16). Background corrections were made using the Shirley method [20] for the C1s, 
O1s, Fe2p, Cu2p, S2p, and Mo3d spectra. The peak shapes were defined using a Gaussian-Lorentzian function. The binding energy $\left(E_{B}\right)$ calibration was based on $C 1 \mathrm{~s}$ at $E_{B}[\mathrm{C} 1 \mathrm{~s}]=284.6 \mathrm{eV}$.

\subsection{Flotation Study}

To examine the effect of $\mathrm{Na}_{2} \mathrm{SO}_{3}$ on the floatability of both minerals, flotation tests were conducted in the absence of collectors. The floatation tests on each mineral were carried out using a column-type microflotation [16]. A certain amount of mineral powder (ca. $0.6 \mathrm{~g}$ ) was suspended in $180 \mathrm{~mL}$ treatment solution. The mixture was then treated in various concentrations of $\mathrm{Na}_{2} \mathrm{SO}_{3}$ for 60 min at the natural $\mathrm{pH}$ of the solution ( $\mathrm{pH} 10.8$ ). Following the mineral treatment, MIBC (22 ppm) was added as a frother. The conditioning time for the frother was $2 \mathrm{~min}$. Afterwards, the flotation test was started by injecting the nitrogen gas into the glass column at a flow rate of $20 \mathrm{~mL} / \mathrm{min}$ for $1 \mathrm{~min}$. The float and sink fractions were collected separately, filtered, dried in an oven at $105^{\circ} \mathrm{C}$ for $12 \mathrm{~h}$, and weighed. The mineral recovery reported in this work was calculated based on the mass percentage of the float fraction.

\section{Results and Discussion}

\subsection{Contact Angle}

The effect of $\mathrm{Na}_{2} \mathrm{SO}_{3}$ on surface wettability of chalcopyrite and molybdenite is presented in Figure 1. Contact angle values of chalcopyrite and molybdenite were ca. $71^{\circ}$ and $67^{\circ}$, respectively, after the pretreatment using TMD solution at $\mathrm{pH}$ 8. At higher $\mathrm{pH}$ values, the contact angle of chalcopyrite significantly increased to ca. $81^{\circ}$. Meanwhile, the contact angle of molybdenite was slightly affected by increasing $\mathrm{pH}$ value, with the exception at $\mathrm{pH} 9$, where the contact angle of molybdenite slightly increased to ca. $71^{\circ}$.
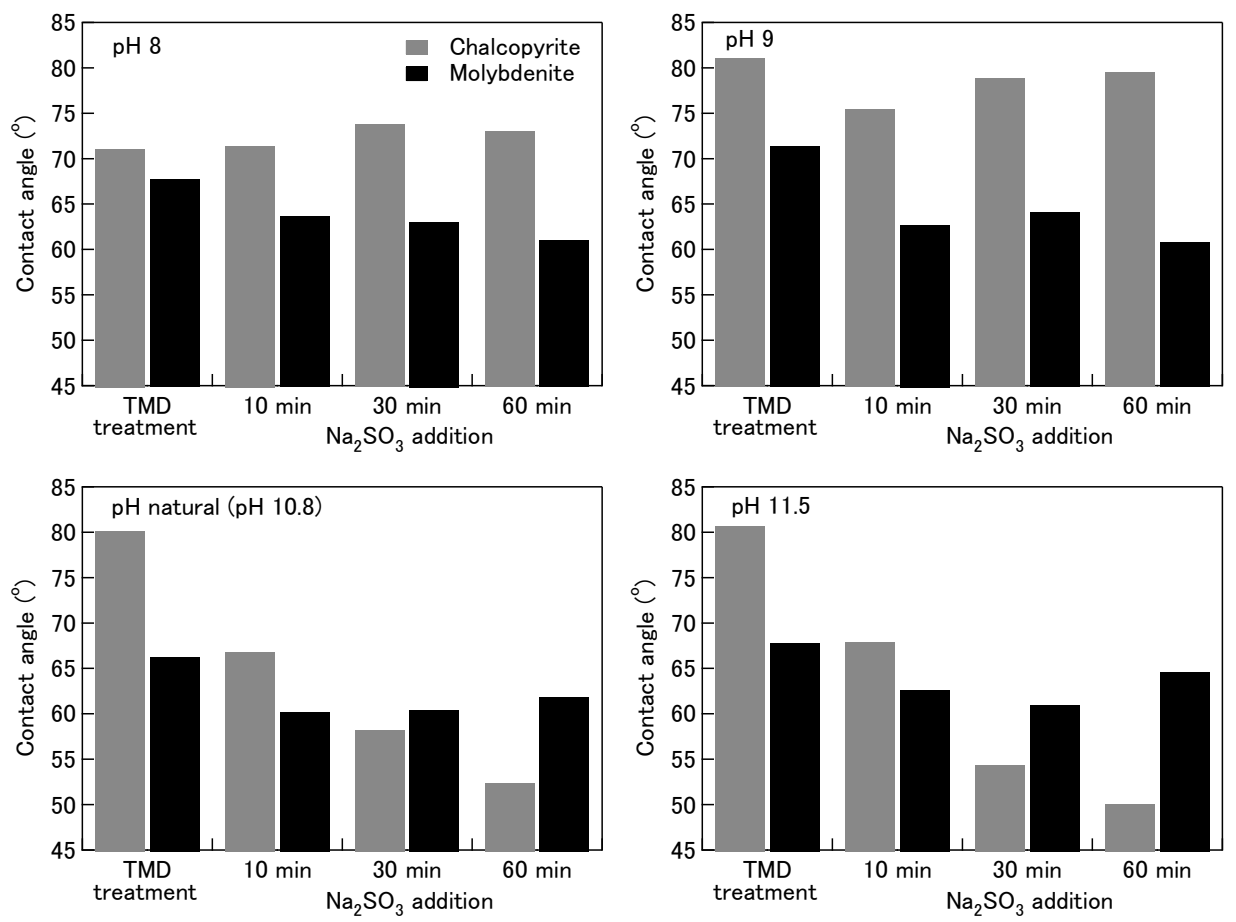

Figure 1. Contact angle of chalcopyrite and molybdenite at various $\mathrm{pH}$ values after the pretreatment using TMD solution followed by treatment using $0.1 \mathrm{M} \mathrm{Na}_{2} \mathrm{SO}_{3}$ for $10-60 \mathrm{~min}$.

In the presence of $0.1 \mathrm{M} \mathrm{Na}_{2} \mathrm{SO}_{3}$ at $\mathrm{pH} 8$, the contact angle of chalcopyrite slightly increased with increasing treatment time. On the other hand, the contact angle of molybdenite slightly decreased with increasing treatment time. A similar phenomenon can be observed at pH 9 (Figure 1). However, 
the contact angle of chalcopyrite significantly decreased with increasing treatment time at the natural $\mathrm{pH}$ of $\mathrm{Na}_{2} \mathrm{SO}_{3}$ aqueous solution ( $\mathrm{pH}$ 10.8). A similar phenomenon happened at $\mathrm{pH} 11.5$, indicating that the chalcopyrite surface became more hydrophilic after the $\mathrm{Na}_{2} \mathrm{SO}_{3}$ treatment. Under similar $\mathrm{pH}$ conditions, the contact angle of molybdenite was slightly decreased after the treatment. The contact angle results at $\mathrm{pH}$ higher than 9 indicate that $\mathrm{Na}_{2} \mathrm{SO}_{3}$ could selectively alter the surface wettability of chalcopyrite after the pretreatment with TMD solution. In addition, these results demonstrate that the $\mathrm{Na}_{2} \mathrm{SO}_{3}$ treatment might be applied for selective flotation of chalcopyrite and molybdenite.

The phenomena observed in Figure 1 can be explained by the following assumptions. The flotation collectors-TX15216 (alkyl mercaptan) and AERO ${ }^{\circledR}$ MX-7017 (modified thionocarbamate) -are mainly used for selective flotation of copper minerals. Meanwhile, diesel oil is usually used to improve the floatability of molybdenite. TX15216 and AERO ${ }^{\circledR}$ MX-7017 can be adsorbed on the mineral surface through physical and chemical adsorption. At higher $\mathrm{pH}$, these collectors can be more ionized, thus increasing the chemical adsorption compared with the physical adsorption. Therefore, a higher contact angle value of chalcopyrite could be obtained with increasing $\mathrm{pH}$. Unlike the alkyl mercaptan and modified thionocarbamate used in this study, diesel oil is a nonpolar collector and, thus, cannot be ionized in the aqueous solution. In addition, diesel oil is physically adsorbed on the molybdenite surface. Therefore, the $\mathrm{pH}$ has a little effect on the adsorption of diesel oil on the molybdenite surface.

The selective conversion of surface wettability of chalcopyrite at high $\mathrm{pH}$ values in $0.1 \mathrm{M} \mathrm{Na}_{2} \mathrm{SO}_{3}$ might be caused by the effect of $\mathrm{Na}_{2} \mathrm{SO}_{3}$ on reducing the ionization of collectors, thus reducing the adsorbed collector on the chalcopyrite surface. On the other hand, as diesel oil is a nonpolar collector, the presence of $\mathrm{Na}_{2} \mathrm{SO}_{3}$ had a slight effect on the adsorption of this collector on the molybdenite surface; this resulted in the relatively higher contact angle value of molybdenite than that of chalcopyrite.

It is difficult to understand the role of $\mathrm{Na}_{2} \mathrm{SO}_{3}$ in affecting the surface hydrophobicity of chalcopyrite and molybdenite in the presence of the TMD solution. Therefore, to simplify the process, contact angle measurements were then conducted without pretreatment using TMD solution; the results are presented in Figure 2. It can be seen that the contact angle values of untreated chalcopyrite and molybdenite were lower in the absence of TMD solution compared with those of the pretreatment using TMD solution (Figure 1), demonstrating the effect of TMD collectors on improving the hydrophobicity of both minerals.
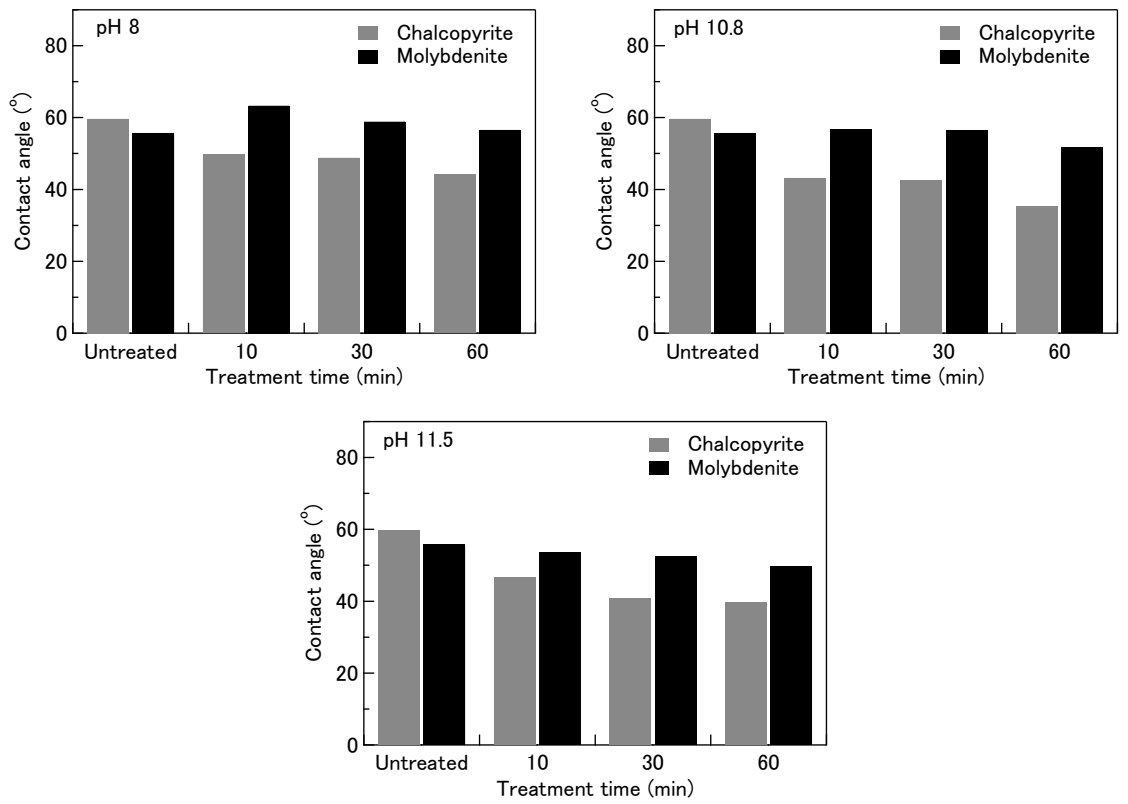

Figure 2. Effect of $0.1 \mathrm{M} \mathrm{Na}_{2} \mathrm{SO}_{3}$ on contact angle of chalcopyrite and molybdenite at various $\mathrm{pH}$ values and treatment times without pretreatment using TMD solution. 
Figure 2 shows that the contact angle of chalcopyrite decreased after treated in $0.1 \mathrm{M} \mathrm{Na}_{2} \mathrm{SO}_{3}$. Moreover, the contact angle values of chalcopyrite decreased with increasing treatment time and $\mathrm{pH}$, especially at $\mathrm{pH} 10.8$ and 11.5 , suggesting that $\mathrm{Na}_{2} \mathrm{SO}_{3}$ reduces the natural hydrophobicity of the chalcopyrite surface in the absence of TMD solution. On the other hand, the contact angle values of molybdenite slightly decreased with increasing treatment time and $\mathrm{pH}$ of $0.1 \mathrm{M} \mathrm{Na}_{2} \mathrm{SO}_{3}$ without the pretreatment (Figure 2). These results indicate that the surface of the molybdenite was slightly affected by the $\mathrm{Na}_{2} \mathrm{SO}_{3}$ treatment in the absence of the TMD solution.

The contact angle results presented in Figures 1 and 2 may suggest the role of $\mathrm{Na}_{2} \mathrm{SO}_{3}$ treatment. The $\mathrm{Na}_{2} \mathrm{SO}_{3}$ treatment might reduce the adsorbed TMD on the chalcopyrite and molybdenite surface, exposing a kind of "fresh" surface of both minerals. On this "fresh" surface of chalcopyrite, the $\mathrm{Na}_{2} \mathrm{SO}_{3}$ treatment might further reduce the surface hydrophobicity. On the other hand, the "fresh" molybdenite surface is only slightly affected by the $\mathrm{Na}_{2} \mathrm{SO}_{3}$ treatment, therefore resulting in a more hydrophobic surface compared to that of the chalcopyrite. However, the proposed mechanism needs further investigation and will be addressed in future work.

\subsection{XPS Analysis}

XPS analysis results of chalcopyrite and molybdenite are presented in Figures 3 and 4, respectively. It should be noted that the XPS analysis was conducted in the absence of collector in order to simplify the surface analysis and to examine the effect of $\mathrm{Na}_{2} \mathrm{SO}_{3}$ on the chemical composition of the chalcopyrite and molybdenite surfaces. Figure 3 shows the copper $(\mathrm{Cu}) 2 p$, iron $(\mathrm{Fe}) 2 p$, sulfur $(\mathrm{S}) 2 p$, and oxygen $(\mathrm{O}) 1 \mathrm{~s}$ spectra of chalcopyrite. The $\mathrm{Cu} 2 \mathrm{p}$ of the untreated chalcopyrite spectra (Figure 3) can be best fitted with three Gaussian-Lorentzian functions located at ca. 932.0, 932.7, and 934.2 eV. The binding energy located at ca. $932.0 \mathrm{eV}$ corresponds to chalcopyrite according to Nakai et al. [21]. Meanwhile, the higher binding energies correspond to $\mathrm{CuO}(\mathrm{ca} .932 .7 \mathrm{eV})$ and $\mathrm{Cu}(\mathrm{OH})_{2}(\mathrm{ca} .934 .2 \mathrm{eV})$, as reported by Hussain et al. [22] and McIntyre and Cook [23], respectively. This result indicates that the untreated chalcopyrite surface was slightly oxidized, forming $\mathrm{CuO}$ and $\mathrm{Cu}(\mathrm{OH})_{2}$ species, likely due to surface oxidation by cleaning treatment using $\mathrm{HNO}_{3}$ aqueous solution. Indeed, the oxidation of the untreated surface is confirmed from the presence of monosulfide $(\mathrm{S})$ and octasulfur $\left(\mathrm{S}_{8}\right)$ on the chalcopyrite surface as indicated from the S2p peaks located at ca. $162.7 \mathrm{eV}$ [24] and ca. $164.6 \mathrm{eV}$ [25], respectively. The Cu2p spectrum of the treated chalcopyrite surface using $0.1 \mathrm{M} \mathrm{Na}_{2} \mathrm{SO}_{3}$ at $\mathrm{pH} 8$ shows the presence of similar $\mathrm{Cu}$ species as the untreated surface. However, the chalcopyrite surface was dominated by $\mathrm{CuO}$ species at $\mathrm{pH} 10.8$, indicating the transformation of a metastable copper hydroxide to a more stable copper oxide [26].

Unlike the untreated surface, the S2p spectrum in Figure 3 suggests that the surface was more oxidized after the $\mathrm{Na}_{2} \mathrm{SO}_{3}$ treatment for all $\mathrm{pH}$ values, as indicated from the appearance of a new peak located at higher binding energy (ca. $168.0 \mathrm{eV}$ ), which corresponds to ferric sulfate $\left(\mathrm{Fe}_{2}\left(\mathrm{SO}_{4}\right)_{3}\right)$ [27]. Moreover, the deconvolution results of the new peak suggest the presence of $\mathrm{Na}_{2} \mathrm{SO}_{3}$ and its oxidation product, sodium sulfate $\left(\mathrm{Na}_{2} \mathrm{SO}_{4}\right)$, on the chalcopyrite surface as indicated from the peaks located at ca. $166.4 \mathrm{eV}$ and $168.5 \mathrm{eV}$, respectively [28].

The Fe2p spectrum in Figure 3 indicates that the chalcopyrite peak located at ca. $708.2 \mathrm{eV}$ [29] on the untreated surface shifted to a lower binding energy located at ca. $707.1 \mathrm{eV}$ after treated in $0.1 \mathrm{M}$ $\mathrm{Na}_{2} \mathrm{SO}_{3}$ at $\mathrm{pH} 10.8$. This binding energy corresponds to iron disulfide $\left(\mathrm{FeS}_{2}\right)$ as reported by Laajalehto et al. [30]. A similar phenomenon can be observed from the Fe2p spectrum of treated chalcopyrite at $\mathrm{pH}$ 11.5. The presence of $\mathrm{FeS}_{2}$ is confirmed from the S2p spectrum as shown by the peak located at ca. $162.1 \mathrm{eV}$ [31]. Moreover, the S2p spectrum suggests the presence of iron sulfide (FeS) on the chalcopyrite surface after the treatment at $\mathrm{pH} 10.8$ and 11.5, as indicated from the peak located at lower binding energy, ca. $160.6 \mathrm{eV}$ [28]. Iron sulfide has binding energy at ca. $710.1 \mathrm{eV}$ [32] in the Fe2p spectrum (Figure 3). However, at pH 10.8, the peak of Fe2p located at ca. $711.2 \mathrm{eV}$, which is attributed to $\mathrm{FeOOH}$ [33], became more apparent, indicating an increased concentration of $\mathrm{FeOOH}$ on the surface. 


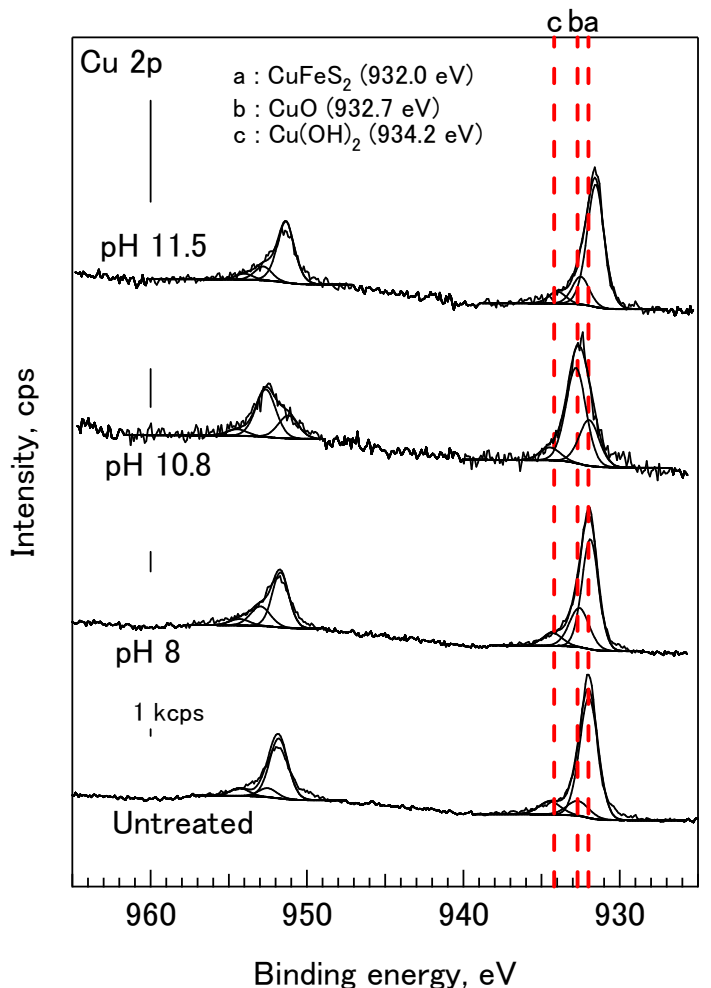

(a)

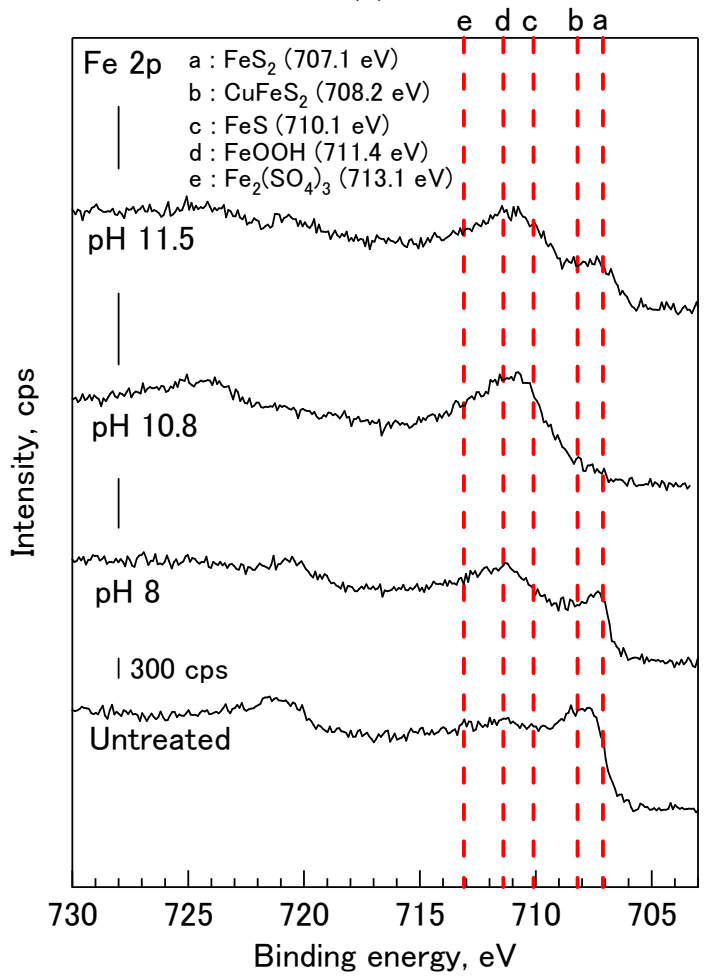

(c)

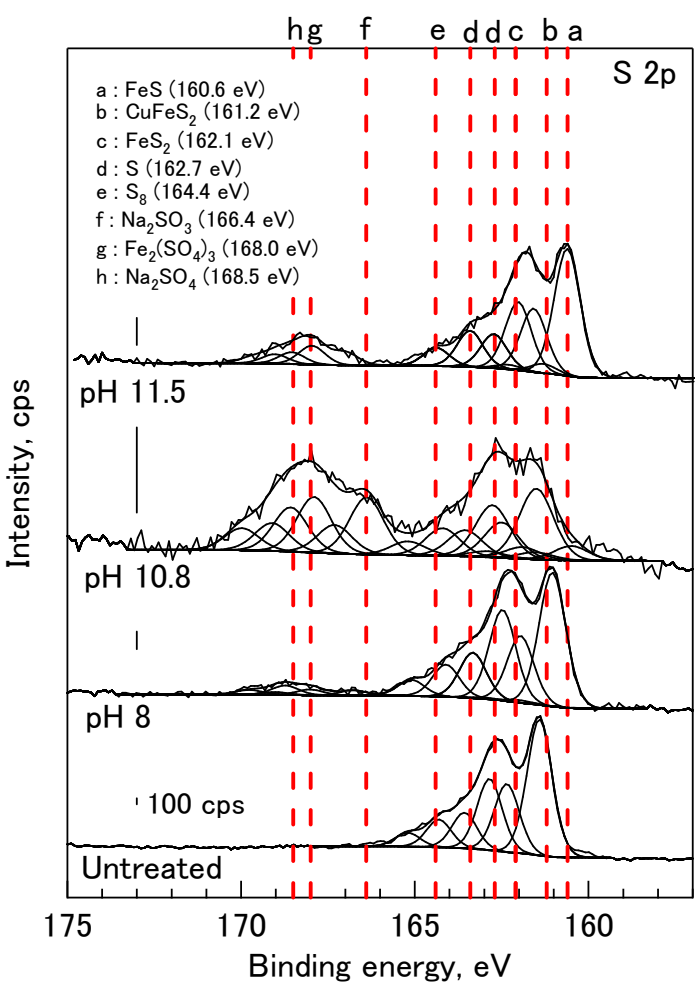

(b)

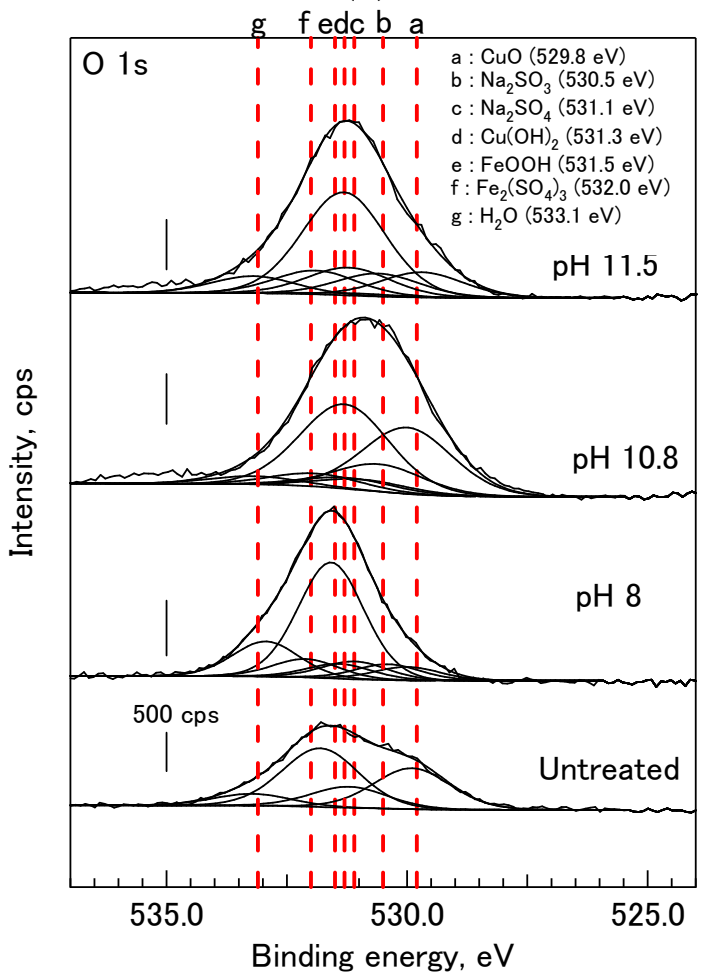

(d)

Figure 3. The Cu2p (a); S2p (b); Fe2p (c); and O1s (d) spectra of untreated and treated chalcopyrite with $0.1 \mathrm{M} \mathrm{Na}_{2} \mathrm{SO}_{3}$ treatment for $60 \mathrm{~min}$ at various $\mathrm{pH}$ conditions. 


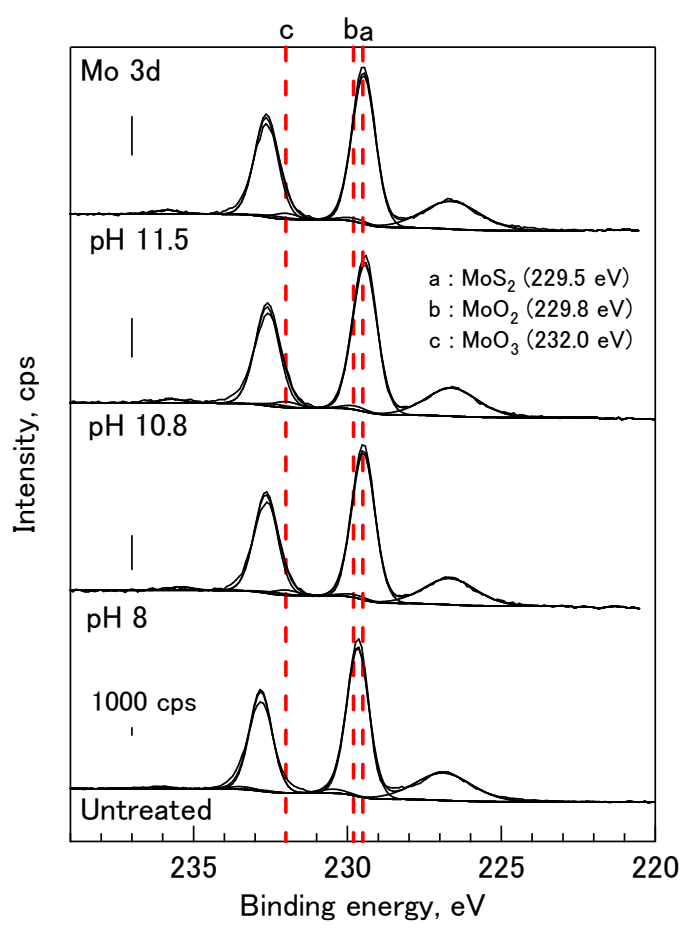

(a)

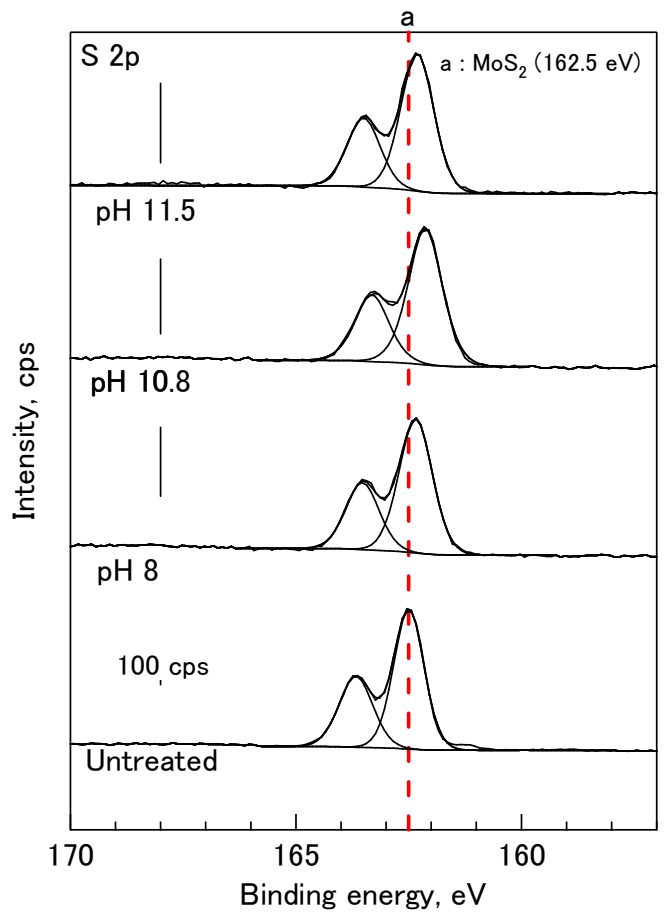

(b)

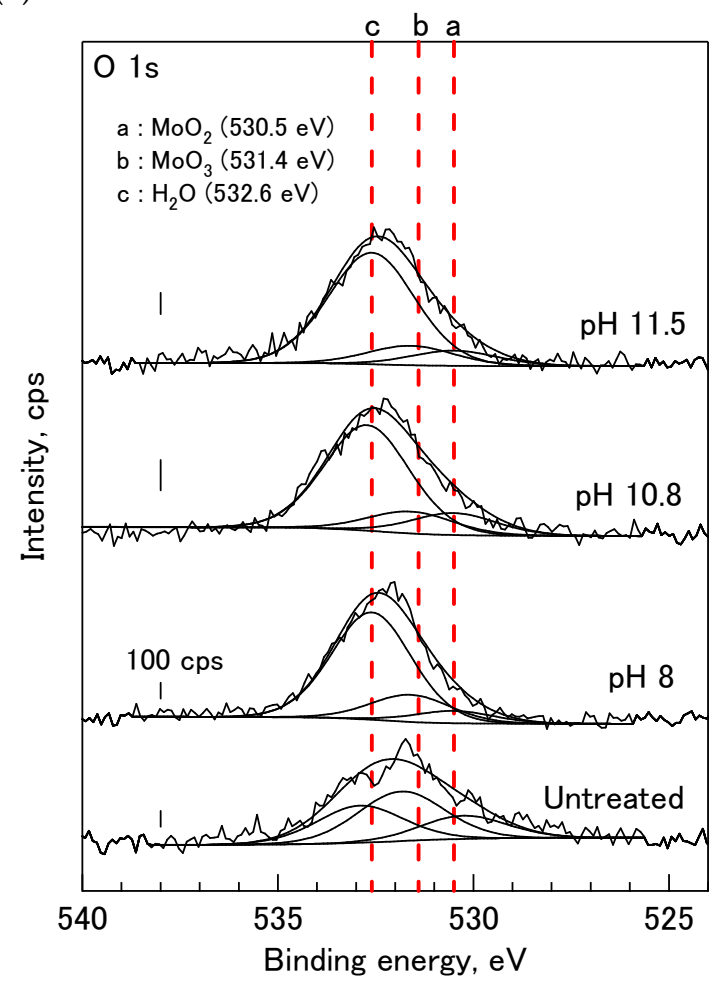

(c)

Figure 4. The Mo3d (a); S2p (b); and O1s (c) spectra of untreated and treated molybdenite with $0.1 \mathrm{M}$ $\mathrm{Na}_{2} \mathrm{SO}_{3}$ treatment at various $\mathrm{pH}$ conditions.

The O1s spectrum presented in Figure 3 confirms the formation of various oxides, sulfite, and sulfate on the chalcopyrite surface. The oxygen from $\mathrm{CuO}, \mathrm{Cu}(\mathrm{OH})_{2}$, and $\mathrm{FeOOH}$ are located at ca. $529.8 \mathrm{eV}$ [34], $531.3 \mathrm{eV}$ [35], and $531.5 \mathrm{eV}$ [36], respectively. Meanwhile, the oxygen from $\mathrm{Na}_{2} \mathrm{SO}_{3}$, 
$\mathrm{Na}_{2} \mathrm{SO}_{4}$, and $\mathrm{Fe}_{2}\left(\mathrm{SO}_{4}\right)_{3}$ are located at ca. $530.5 \mathrm{eV}$ [37], $531.1 \mathrm{eV}$ [38], and $532.0 \mathrm{eV}$ [29]. In addition, the deconvolution peak of O1s located at ca. $533.1 \mathrm{eV}$ corresponds to $\mathrm{H}_{2} \mathrm{O}$ [39].

The XPS results presented in Figure 3 show that the $\mathrm{Na}_{2} \mathrm{SO}_{3}$ treatment produced various hydrophilic species (i.e., $\mathrm{CuO}, \mathrm{Cu}(\mathrm{OH})_{2}, \mathrm{FeOOH}$, and $\left.\mathrm{Fe}_{2}\left(\mathrm{SO}_{4}\right)_{3}\right)$ which covered the chalcopyrite surface. The presence of these hydrophilic species could alter its surface hydrophobicity as shown in Figures 1 and 2. Moreover, the decrease in $\mathrm{Cu} 2 \mathrm{p}$ peak intensity of chalcopyrite with increasing $\mathrm{pH}$ indicates that the coverage of hydrophilic species on the chalcopyrite surface increased, thus reducing the hydrophobicity. Based on the XPS results, the following possible mechanism is proposed to understand the effect of $\mathrm{Na}_{2} \mathrm{SO}_{3}$ treatment on chalcopyrite surface. If $\mathrm{SO}_{3}{ }^{2-}$ ions from $\mathrm{Na}_{2} \mathrm{SO}_{3}$ can act as a reducing agent, chalcopyrite can react with $\mathrm{SO}_{3}{ }^{2-}$ following Equation (1).

$$
2 \mathrm{CuFeS}_{2}+6 \mathrm{Cu}^{2+}+3 \mathrm{SO}_{3}^{2-}+6 \mathrm{OH}^{-} \rightarrow 4 \mathrm{Cu}_{2} \mathrm{~S}+2 \mathrm{Fe}^{3+}+3 \mathrm{SO}_{4}^{2-}+3 \mathrm{H}_{2} \mathrm{O}
$$

It is known that the produced $\mathrm{Cu}_{2} \mathrm{~S}$ is easily oxidized following Equation (2).

$$
\mathrm{Cu}_{2} \mathrm{~S} \rightarrow 2 \mathrm{Cu}^{2+}+\mathrm{S}+4 \mathrm{e}^{-}
$$

The ferric ion forms precipitates at alkaline conditions. The following reactions are proposed for the precipitations.

$$
\begin{gathered}
\mathrm{Fe}^{3+}+3 \mathrm{OH}^{-} \rightarrow \mathrm{FeOOH}+\mathrm{H}_{2} \mathrm{O} \\
2 \mathrm{Fe}^{3+}+3 \mathrm{SO}_{4}^{2-} \rightarrow \mathrm{Fe}_{2}\left(\mathrm{SO}_{4}\right)_{3}
\end{gathered}
$$

The XPS spectra of untreated and treated molybdenite presented in Figure 4 show that the molybdenite surface was slightly affected by the $\mathrm{Na}_{2} \mathrm{SO}_{3}$ treatment, in agreement with the contact angle results presented in Figure 2. The molybdenite $\left(\mathrm{MoS}_{2}\right)$ species can be seen from the peak located at ca. $229.5 \mathrm{eV}$ in the Mo3d spectrum [40]. Moreover, the S2p spectrum shows a peak located at ca. $162.5 \mathrm{eV}$ which corresponds to the $\mathrm{MoS}_{2}$ species [41]. The Mo3d spectrum of untreated molybdenite suggests that the surface was slightly oxidized as indicated from the peaks located at ca. 229.8 and $232.0 \mathrm{eV}$. These peaks are attributed to $\mathrm{MoO}_{2}$ [42] and $\mathrm{MoO}_{3}$ [43], respectively. The O1s spectrum confirms the presence of $\mathrm{MoO}_{2}$ and $\mathrm{MoO}_{3}$, as indicated by the peaks located at ca. $530.5 \mathrm{eV}$ [43] and ca. $531.4 \mathrm{eV}$ [44]. The treated molybdenite spectra show similar species present as observed on untreated surface, indicating that the surface was slightly affected by the $\mathrm{Na}_{2} \mathrm{SO}_{3}$ treatment; thus, the surface remained hydrophobic.

\subsection{Flotation Tests}

The effect of $\mathrm{Na}_{2} \mathrm{SO}_{3}$ on the floatability of single minerals of chalcopyrite and molybdenite without pretreatment using the TMD solution is presented in Figure 5. As shown in this figure, chalcopyrite recovery decreased gradually with increasing concentration of $\mathrm{Na}_{2} \mathrm{SO}_{3}$. Indeed, chalcopyrite recovery was almost zero after treatment with $0.1 \mathrm{M} \mathrm{Na}_{2} \mathrm{SO}_{3}$ for $60 \mathrm{~min}$. The reason for this phenomenon might be the formation of hydrophilic precipitates on the chalcopyrite surface as shown from XPS and contact angle results. On the other hand, molybdenite recovery gradually increased with increasing concentration of $\mathrm{Na}_{2} \mathrm{SO}_{3}$ and reached ca. $95 \%$ after treatment with $0.07 \mathrm{M} \mathrm{Na}_{2} \mathrm{SO}_{3}$. These results support the contact angle and XPS results, showing that the surface of molybdenite remained hydrophobic after the treatment. It should be noted that the use of MIBC as a frother in the flotation tests might affect the floatability of molybdenite. However, the effect of this straight alcohol frother on molybdenite recovery is lower than those of the aromatic alcohols (i.e., pine oil) and alkoxy paraffin [2]. The flotation results of pure mineral suggest that $\mathrm{Na}_{2} \mathrm{SO}_{3}$ might be effective for selective separation of chalcopyrite and molybdenite, which will be addressed in future work. 


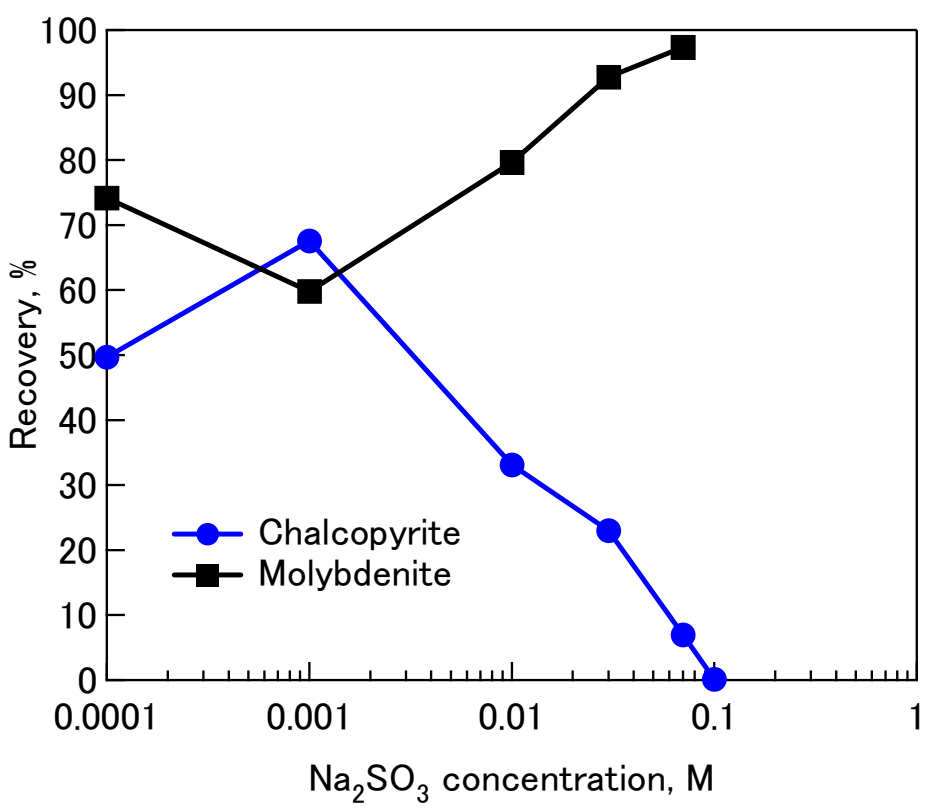

Figure 5. Effect of various concentrations of $\mathrm{Na}_{2} \mathrm{SO}_{3}$ on floatability of single minerals of chalcopyrite and molybdenite at $\mathrm{pH} 10.8$.

\section{Conclusions}

The effect of $\mathrm{Na}_{2} \mathrm{SO}_{3}$ on surface wettability and floatability of chalcopyrite and molybdenite was investigated in this study. Contact angle measurements showed that contact angle of chalcopyrite gradually decreased with increasing concentration of $\mathrm{Na}_{2} \mathrm{SO}_{3}$. XPS results of chalcopyrite showed that various hydrophilic species (i.e., $\left.\mathrm{CuO}, \mathrm{Cu}(\mathrm{OH})_{2}, \mathrm{FeOOH}, \mathrm{Fe}_{2}\left(\mathrm{SO}_{4}\right)_{3}\right)$ formed on the surface after the $\mathrm{Na}_{2} \mathrm{SO}_{3}$ treatment. These hydrophilic species might be the reason for the decreasing contact angle of the chalcopyrite. A mechanism was proposed to explain the formation of these hydrophilic species via a reduction of chalcopyrite to $\mathrm{Cu}_{2} \mathrm{~S}$ followed by the oxidation of $\mathrm{Cu}_{2} \mathrm{~S}$. On the other hand, contact angle readings show that the molybdenite had a more hydrophobic surface compared with that of chalcopyrite after the treatment. The XPS results of molybdenite confirm the contact angle results, indicating that the surface was slightly affected by the $\mathrm{Na}_{2} \mathrm{SO}_{3}$ treatment.

Flotation of single mineral demonstrated that $\mathrm{Na}_{2} \mathrm{SO}_{3}$ depressed chalcopyrite floatability at a higher concentration, likely due to the decrease in the surface hydrophobicity of chalcopyrite. Meanwhile, the floatability of molybdenite gradually increased with increasing concentration of $\mathrm{Na}_{2} \mathrm{SO}_{3}$. The flotation results suggest that $\mathrm{Na}_{2} \mathrm{SO}_{3}$ might be effective for separation of these two minerals. However, further investigation is needed in the future to assess the effect of $\mathrm{Na}_{2} \mathrm{SO}_{3}$ on mixed minerals of chalcopyrite and molybdenite.

Acknowledgments: This work was supported by a Grant-in-Aid for Science Research (JSPS KAKENHI Grant No. JP15H02333 and No. JP16K06929) from the Japan Society for the Promotion of Science (JSPS)—Japan, the Sumitomo Metal Mining Co., Ltd., Japan, and the Ministry of Education, Culture, Sports, Science and Technology of Japan (MEXT).

Author Contributions: H.M. wrote the paper under the supervision of T.H. and K.S. who were also heavily involved in all stages of preparing this paper. Y.M. collected the experimental data with help from G.P.W.S., who also analyzed the XPS data and helped in writing the manuscript.

Conflicts of Interest: The authors declare no conflict of interest.

\section{References}

1. Ansari, A.; Pawlik, M. Floatability of chalcopyrite and molybdenite in the presence of lignosulfonates. Part II. Hallimond tube flotation. Miner. Eng. 2007, 20, 609-616. [CrossRef] 
2. Bulatovic, S.M. Handbook of Flotation Reagents; Elsevier Science \& Technology Books: Amsterdam, The Netherlands, 2007.

3. Moreno, P.A.; Aral, H.; Cuevas, J.; Monardes, A.; Adaro, M.; Norgate, T.; Bruckard, W. The use of seawater as process water at Las Luces copper-molybdenum beneficiation plant in Taltal (Chile). Miner. Eng. 2011, 24, 852-858. [CrossRef]

4. Pearse, M.J. An overview of the use of chemical reagents in mineral processing. Miner. Eng. 2005, 18, 139-149. [CrossRef]

5. Prasad, M.S. Reagents in the mineral industry-Recent trends and applications. Miner. Eng. Spec. Issue Reag. Miner. Eng. 1992, 5, 279-294. [CrossRef]

6. Somasundaran, P. Reagents in Mineral Technology; CRC Press: Boca Raton, FL, USA, 1987.

7. Yin, W.; Zhang, L.; Xie, F. Flotation of Xinhua molybdenite using sodium sulfide as modifier. Trans. Nonferrous Met. Soc. China 2010, 20, 702-706. [CrossRef]

8. Wills, B.A.; Napier-Munn, T.J. Mineral Processing Technology; Elsevier Science \& Technology Books: Amsterdam, The Netherlands, 2006.

9. Liu, G.; Lu, Y.; Zhong, H.; Cao, Z.; Xu, Z. A novel approach for preferential flotation recovery of molybdenite from a porphyry copper-molybdenum ore. Miner. Eng. 2012, 36, 37-44. [CrossRef]

10. Zanin, M.; Ametov, I.; Grano, S.; Zhou, L.; Skinner, W. A study of mechanisms affecting molybdenite recovery in a bulk copper/molybdenum flotation circuit. Int. J. Miner. Process. 2009, 93, 256-266. [CrossRef]

11. Ansari, A.; Pawlik, M. Floatability of chalcopyrite and molybdenite in the presence of lignosulfonates. Part I. Adsorption studies. Miner. Eng. 2007, 20, 600-608. [CrossRef]

12. Shen, W.Z.; Fornasiero, D.; Ralston, J. Flotation of sphalerite and pyrite in the presence of sodium sulfite. Int. J. Miner. Process. 2001, 63, 17-28. [CrossRef]

13. Haga, K.; Tongamp, W.; Shibayama, A. Investigation of flotation parameters for copper recovery from enargite and chalcopyrite mixed ore. Mater. Trans. 2012, 53, 707-715. [CrossRef]

14. Houot, R.; Duhamet, D. Floatability of chalcopyrite in the presence of dialkyl-thionocarbamate and sodium sulfite. Int. J. Miner. Process. 1993, 37, 273-282. [CrossRef]

15. Suyantara, G.P.W.; Hirajima, T.; Elmahdy, A.M.; Miki, H.; Sasaki, K. Effect of kerosene emulsion in $\mathrm{MgCl}_{2}$ solution on the kinetics of bubble interactions with molybdenite and chalcopyrite. Colloids Surf. A Physicochem. Eng. Asp. 2016, 501, 98-113. [CrossRef]

16. Suyantara, G.P.W.; Hirajima, T.; Miki, H.; Sasaki, K. Floatability of molybdenite and chalcopyrite in artificial seawater. Miner. Eng. 2018, 115, 117-130. [CrossRef]

17. Hirajima, T.; Miki, H.; Suyantara, G.P.W.; Matsuoka, H.; Elmahdy, A.M.; Sasaki, K.; Imaizumi, Y.; Kuroiwa, S. Selective flotation of chalcopyrite and molybdenite with $\mathrm{H}_{2} \mathrm{O}_{2}$ oxidation. Miner. Eng. 2017, 100, 83-92. [CrossRef]

18. Miki, H.; Matsuoka, H.; Hirajima, T.; Suyantara, G.P.W.; Sasaki, K. Electrolysis Oxidation of Chalcopyrite and Molybdenite for Selective Flotation. Mater. Trans. 2017, 58, 761-767.

19. Hirajima, T.; Mori, M.; Ichikawa, O.; Sasaki, K.; Miki, H.; Farahat, M.; Sawada, M. Selective flotation of chalcopyrite and molybdenite with plasma pre-treatment. Miner. Eng. Froth Flotat. 2014, 66, 102-111. [CrossRef]

20. Shirley, D.A. High-Resolution X-ray Photoemission Spectrum of the Valence Bands of Gold. Phys. Rev. B 1972, 5, 4709-4714. [CrossRef]

21. Nakai, I.; Sugitani, Y.; Nagashima, K.; Niwa, Y. X-ray photoelectron spectroscopic study of copper minerals. J. Inorg. Nucl. Chem. 1978, 40, 789-791. [CrossRef]

22. Hussain, Z.; Salim, M.A.; Khan, M.A.; Khawaja, E.E. X-ray photoelectron and auger spectroscopy study of copper-sodium-germanate glasses. J. Non-Cryst. Solids 1989, 110, 44-52. [CrossRef]

23. McIntyre, N.S.; Cook, M.G. X-ray photoelectron studies on some oxides and hydroxides of cobalt, nickel, and copper. Anal. Chem. 1975, 47, 2208-2213. [CrossRef]

24. Hollinger, G.; Kumurdjian, P.; Mackowski, J.M.; Pertosa, P.; Porte, L.; Duc, T.M. ESCA study of molecular $\mathrm{GeS}_{3}-\mathrm{x}$ Tex As 2 glasses. J. Electron Spectrosc. Relat. Phenom. 1974, 5, 237-245. [CrossRef]

25. Thomas, J.M.; Adams, I.; Williams, R.H.; Barber, M. Valence band structures and core-electron energy levels in the monochalcogenides of gallium. Photoelectron spectroscopic study. J. Chem. Soc. Faraday Trans. 2 1972, $68,755-764$. [CrossRef]

26. Cudennec, Y.; Lecerf, A. The transformation of $\mathrm{Cu}(\mathrm{OH})_{2}$ into $\mathrm{CuO}$, revisited. Solid State Sci. 2003, 5, $1471-1474$. [CrossRef] 
27. Siriwardane, R.V.; Cook, J.M. Interactions of $\mathrm{NO}$ and $\mathrm{SO}_{2}$ with iron deposited on silica. J. Colloid Interface Sci. 1985, 104, 250-257. [CrossRef]

28. Yu, X.R.; Liu, F.; Wang, Z.Y.; Chen, Y. Auger parameters for sulfur-containing compounds using a mixed aluminum-silver excitation source. J. Electron Spectrosc. Relat. Phenom. 1990, 50, 159-166. [CrossRef]

29. Brion, D. Etude par spectroscopie de photoelectrons de la degradation superficielle de $\mathrm{FeS}_{2}, \mathrm{CuFeS}_{2}, \mathrm{ZnS}$ et PbS a l'air et dans l'eau. Appl. Surf. Sci. 1980, 5, 133-152. [CrossRef]

30. Laajalehto, K.; Kartio, I.; Nowak, P. XPS study of clean metal sulfide surfaces. Appl. Surf. Sci. 1994, 81, 11-15. [CrossRef]

31. Karthe, S.; Szargan, R.; Suoninen, E. Oxidation of pyrite surfaces: A photoelectron spectroscopic study. Appl. Surf. Sci. 1993, 72, 157-170. [CrossRef]

32. Carver, J.C.; Schweitzer, G.K.; Carlson, T.A. Use of X-Ray Photoelectron Spectroscopy to Study Bonding in Cr, Mn, Fe, and Co Compounds. J. Chem. Phys. 1972, 57, 973-982. [CrossRef]

33. Buckley, A.N.; Woods, R. An X-ray photoelectron spectroscopic study of the oxidation of chalcopyrite. Aust. J. Chem. 1984, 37, 2403-2413. [CrossRef]

34. Strohmeier, B.R.; Leyden, D.E.; Field, R.S.; Hercules, D.M. Surface spectroscopic characterization of $\mathrm{CuAl}_{2} \mathrm{O}_{3}$ catalysts. J. Catal. 1985, 94, 514-530. [CrossRef]

35. Deroubaix, G.; Marcus, P. X-ray photoelectron spectroscopy analysis of copper and zinc oxides and sulphides. Surf. Interface Anal. 1992, 18, 39-46. [CrossRef]

36. Tan, B.J.; Klabunde, K.J.; Sherwood, P.M.A. X-ray photoelectron spectroscopy studies of solvated metal atom dispersed catalysts. Monometallic iron and bimetallic iron-cobalt particles on alumina. Chem. Mater. 1990, 2, 186-191. [CrossRef]

37. Siriwardane, R.V.; Cook, J.M. Interactions of $\mathrm{SO}_{2}$ with sodium deposited on CaO. J. Colloid Interface Sci. 1986, 114, 525-535. [CrossRef]

38. Terlingen, J.G.A.; Feijen, J.; Hoffman, A.S. Immobilization of surface active compounds on polymer supports using glow discharge processes: 1. Sodium dodecyl sulfate on poly(propylene). J. Colloid Interface Sci. 1993, 155, 55-65. [CrossRef]

39. Sasaki, K.; Takatsugi, K.; Ishikura, K.; Hirajima, T. Spectroscopic study on oxidative dissolution of chalcopyrite, enargite and tennantite at different $\mathrm{pH}$ values. Hydrometallurgy 2010, 100, 144-151. [CrossRef]

40. Benoist, L.; Gonbeau, D.; Pfister-Guillouzo, G.; Schmidt, E.; Meunier, G.; Levasseur, A. XPS analysis of lithium intercalation in thin films of molybdenum oxysulphides. Surf. Interface Anal. 1994, 22, $206-210$. [CrossRef]

41. Stevens, G.C.; Edmonds, T. Electron spectroscopy for chemical analysis spectra of molybdenum sulfides. J. Catal. 1975, 37, 544-547. [CrossRef]

42. Seifert, G.; Finster, J.; Müller, H. SW X $\alpha$ calculations and x-ray photoelectron spectra of molybdenum(II) chloride cluster compounds. Chem. Phys. Lett. 1980, 75, 373-377. [CrossRef]

43. Kim, K.S.; Baitinger, W.E.; Amy, J.W.; Winograd, N. ESCA studies of metal-oxygen surfaces using argon and oxygen ion-bombardment. J. Electron Spectrosc. Relat. Phenom. 1974, 5, 351-367. [CrossRef]

44. Patterson, T.A.; Carver, J.C.; Leyden, D.E.; Hercules, D.M. A surface study of cobalt-molybdena-alumina catalysts using X-ray photoelectron spectroscopy. J. Phys. Chem. 1976, 80, 1700-1708. [CrossRef]

(C) 2018 by the authors. Licensee MDPI, Basel, Switzerland. This article is an open access article distributed under the terms and conditions of the Creative Commons Attribution (CC BY) license (http:/ / creativecommons.org/licenses/by/4.0/). 